\title{
Cardiovascular dynamics in ischemic cardiomyopathy during exercise
}

\author{
E. E. van der Wall $\cdot$ J. J. Bax $\cdot$ C. A. Swenne \\ P. Steendijk $\cdot$ M. J. Schalij
}

Received: 27 October 2009/Accepted: 29 October 2009/Published online: 24 November 2009

(C) The Author(s) 2009. This article is published with open access at Springerlink.com

Both echocardiography and cardiac magnetic resonance imaging (CMR) are currently recognized as accurate and reliable means of evaluating cardiac anatomy and ventricular function. Echocardiography is still the mainstay of assessing left ventricular function but over the past years considerable progress has been made in the field of CMR, providing accurate evaluation of left ventricular function particularly in patients with heart failure due to ischemic cardiomyopathy [1-11]. Stress first-pass contrast-enhanced myocardial perfusion CMR can be used to detect subendocardial ischemia and recent studies have demonstrated the high diagnostic accuracy of stress myocardial perfusion CMR for detecting significant coronary artery disease [12-17]. Magnetic resonance angiography (MRA) has been introduced as a method that can provide visualization of all three major coronary arteries, coronary anomalies, coronary bypasses and the aorta within a single three-dimensional acquisition [18-21]. CMR has become the

Editorial comment on the article of Wong et al. (doi:10.1007/s10554-009-9516-4).

E. E. van der Wall $(\bowtie)$. J. J. Bax ·

C. A. Swenne - P. Steendijk · M. J. Schalij

Leiden University Medical Center, Leiden,

The Netherlands

e-mail: E.E.van_der_Wall@lumc.nl first choice imaging modality in complex congenital heart disease [22-26] and imaging great vessels [27, 28].

Over the past years, contrast-enhanced CMR has been used to visualize the transmural extent of myocardial infarction with high spatial resolution [29-34]. Infarcted myocardium appears hyperenhanced compared with normal myocardium when imaged by a late enhancement CMR. The transmural extent of delayed gadolinium enhancement predicts functional outcome after interventional procedures performed in patients with acute myocardial infarction and chronic ischemic heart disease [35-39].

In the current issue of the International Journal of Cardiovascular Imaging, Wong et al. [40] reported 43 patients with ischemic cardiomyopathy (age $59 \pm 9$ years, mean LVEF $24 \pm 8 \%$ ) who underwent cardiopulmonary exercise testing, echocardiography and CMR. The purpose of the study was to examine the relationship between noninvasive measurements of ventricular-vascular coupling (VVC) with exercise tolerance. Measurements of oxygen consumption, carbon dioxide production, heart rate, minute ventilation, tidal volume, and respiratory rate were made both at rest and during exercise. The authors compared the value of VVC versus other traditional determinants of exercise capacity in this population. VVC was defined non-invasively by the ratio of ventricular systolic elastance (Ees) to arterial elastance (Ea). It was clearly shown that both Ea and Ees were markedly depressed at rest irrespective of age 
and gender. There was an unfavorable rightward shift of systolic-pressure-volume relationship implying a reduced stroke efficiency and diminished cardiac reserve during physiological stress. A higher VVC was associated with higher LVEF and RVEF but showed inverse relation to mitral $E$ wave velocity. VVC was independent of arterial stiffness and diastolic dysfunction. The authors concluded that ventricular-arterial coupling at rest may be a clinically important parameter in predicting exercise capacity in patients with advanced heart failure, and may become an additional target for therapeutic interventions.

This article is important for several reasons. First, a multimodality imaging approach was used, whereby echocardiography primarily provided important diastolic function data. CMR allowed the measurement of both volumetric parameters and aortic distensibility. Based on the volume data Ees and Ea could be measured as pertinent parameters of intrinsic cardiovascular dynamicics. In previous studies, the Leiden group represented by Baan en Steendijk et al. already gained world-wide recognition using Ees and Ea measurements obtained with a conductance catheter [41]. These measurements provide true and unique insights in myocardial contractility and ventricular dynamics in various cardiac disease states such as hypertrophic cardiomyopathy, ischemic cardiomyopathy, both before and after cardiac surgery [42-44]. Assessing aortic distensibility with CMR has been shown a very reliable way of assessing aortic stiffness in particular in patients with Marfan's disease [45-47]. Measuring aortic stiffness might of course also be of interest in patients with ischemic cardiomyopathy and it is interesting to notice that the authors found a significant correlation between aortic distensibiltiy and maximum oxygen consumption. In addition, patients with systolic heart failure showed markedly reduced distensibility of the proximal aorta. Lastly, all patients were subjected to metabolic exercise testing which is rather unique for a population with ischemic cardiomyopathy and advanced heart failure, allowing the assessment of oxygen uptake kinetics in these patients [48-50]. Although the clinical implication and integration of this approach has to be awaited because of the sophisticated methodology used, this study adds unique physiological information on the ventricular dynamics in patients with ischemic cardiomyopathy.
Open Access This article is distributed under the terms of the Creative Commons Attribution Noncommercial License which permits any noncommercial use, distribution, and reproduction in any medium, provided the original author(s) and source are credited.

\section{References}

1. van der Wall EE, Vliegen HW, de Roos A, Bruschke AV (1995) Magnetic resonance imaging in coronary artery disease. Circulation 92:2723-2739

2. Bavelaar-Croon CD, Kayser HW, van der Wall EE et al (2000) Left ventricular function: correlation of quantitative gated SPECT and MR imaging over a wide range of values. Radiology 217:572-575

3. Bax JJ, Lamb H, Dibbets P et al (2000) Comparison of gated single-photon emission computed tomography with magnetic resonance imaging for evaluation of left ventricular function in ischemic cardiomyopathy. Am J Cardiol 86:1299-1305

4. Posma JL, Blanksma PK, van der Wall EE, Hamer HP, Mooyaart EL, Lie KI (1996) Assessment of quantitative hypertrophy scores in hypertrophic cardiomyopathy: magnetic resonance imaging versus echocardiography. Am Heart J 132:1020-1027

5. Pluim BM, Beyerbacht HP, Chin JC et al (1997) Comparison of echocardiography with magnetic resonance imaging in the assessment of the athlete's heart. Eur Heart J 18:1505-1513

6. Pluim BM, Chin JC, De Roos A et al (1996) Cardiac anatomy, function and metabolism in elite cyclists assessed by magnetic resonance imaging and spectroscopy. Eur Heart J 17:1271-1278

7. van der Wall EE, den Hollander W, Heidendal GA, Westera G, Majid PA, Roos JP (1981) Dynamic myocardial scintigraphy with $123 \mathrm{I}$-labeled free fatty acids in patients with myocardial infarction. Eur J Nucl Med 6:383-389

8. Braun S, van der Wall EE, Emanuelsson S, Kobrin I (1996) Effects of a new calcium antagonist, mibefradil (Ro 405967), on silent ischemia in patients with stable chronic angina pectoris: a multicenter placebo-controlled study. The mibefradil international study group. J Am Coll Cardiol 27:317-322

9. Holman ER, Buller VG, de Roos A et al (1997) Detection and quantification of dysfunctional myocardium by magnetic resonance imaging. A new three-dimensional method for quantitative wall-thickening analysis. Circulation 95:924-931

10. Schuijf JD, Bax JJ, Shaw LJ et al (2006) Meta-analysis of comparative diagnostic performance of magnetic resonance imaging and multislice computed tomography for noninvasive coronary angiography. Am Heart J 151:404411

11. Ypenburg C, van der Wall EE, Schalij MJ, Bax JJ (2008) Imaging in cardiac resynchronisation therapy. Neth Heart $\mathbf{J}$ 16:S36-S40

12. van Rugge FP, van der Wall EE, Bruschke AV (1992) New developments in pharmacologic stress imaging. Am Heart J 124:468-485 
13. van Rugge FP, Holman ER, van der Wall EE et al (1993) Quantitation of global and regional left ventricular function by cine magnetic resonance imaging during dobutamine stress in normal human subjects. Eur Heart J 14:456-463

14. Pluim BM, Lamb HJ, Kayser HW, Leujes F et al (1998) Functional and metabolic evaluation of the athlete's heart by magnetic resonance imaging and dobutamine stress magnetic resonance spectroscopy. Circulation 97:666-672

15. van Rugge FP, van der Wall EE, Spanjersberg SJ et al (1994) Magnetic resonance imaging during dobutamine stress for detection and localization of coronary artery disease. Quantitative wall motion analysis using a modification of the centerline method. Circulation 90:127-138

16. Nemes A, Geleijnse ML, van Geuns RJ et al (2008) Dobutamine stress MRI versus threedimensional contrast echocardiography: it's all black and white. Neth Heart J 16:217-218

17. Bleeker GB, Bax JJ, Fung JW et al (2006) Clinical versus echocardiographic parameters to assess response to cardiac resynchronization therapy. Am J Cardiol 97:260-263

18. Schuijf JD, Bax JJ, van der Wall EE (2007) Anatomical and functional imaging techniques: basically similar or fundamentally different? Neth Heart J 15:43-44

19. Vliegen HW, Doornbos J, de Roos A, Jukema JW, Bekedam MA, van der Wall EE (1997) Value of fast gradient echo magnetic resonance angiography as an adjunct to coronary arteriography in detecting and confirming the course of clinically significant coronary artery anomalies. Am J Cardiol 79:773-776

20. Hoogendoorn LI, Pattynama PM, Buis B, van der Geest RJ, van der Wall EE, de Roos A (1995) Noninvasive evaluation of aortocoronary bypass grafts with magnetic resonance flow mapping. Am J Cardiol 75:845-848

21. Langerak SE, Vliegen HW, de Roos A et al (2002) Detection of vein graft disease using high-resolution magnetic resonance angiography. Circulation 105:328-333

22. Rebergen SA, Ottenkamp J, Doornbos J, van der Wall EE, Chin JG, de Roos A (1993) Postoperative pulmonary flow dynamics after Fontan surgery: assessment with nuclear magnetic resonance velocity mapping. J Am Coll Cardiol 21:123-131

23. Groenink M, Lohuis TA, Tijssen JG et al (1999) Survival and complication free survival in Marfan's syndrome: implications of current guidelines. Heart 82:499-504

24. Tulevski II, Hirsch A, Sanson BJ et al (2001) Increased brain natriuretic peptide as a marker for right ventricular dysfunction in acute pulmonary embolism. Thromb Haemost 86:1193-1196

25. Niezen RA, Helbing WA, van der Wall EE, van der Geest RJ, Rebergen SA, de Roos A (1996) Biventricular systolic function and mass studied with MR imaging in children with pulmonary regurgitation after repair for tetralogy of Fallot. Radiology 201:135-140

26. Vliegen HW, van Straten A, de Roos A et al (2002) Magnetic resonance imaging to assess the hemodynamic effects of pulmonary valve replacement in adults late after repair of tetralogy of fallot. Circulation 106:1703-1707

27. Oosterhof T, van Straten A, Vliegen HW et al (2007) Preoperative thresholds for pulmonary valve replacement in patients with corrected tetralogy of Fallot using cardiovascular magnetic resonance. Circulation 116:545-551
28. van der Geest RJ, de Roos A, van der Wall EE, Reiber JH (1997) Quantitative analysis of cardiovascular MR images. Int J Card Imaging 13:247-258

29. van der Geest RJ, Niezen RA, van der Wall EE, de Roos A, Reiber JH (1998) Automated measurement of volume flow in the ascending aorta using MR velocity maps: evaluation of inter- and intraobserver variability in healthy volunteers. J Comput Assist Tomogr 22:904-911

30. van der Laarse A, Kerkhof PL, Vermeer F et al (1988) Relation between infarct size and left ventricular performance assessed in patients with first acute myocardial infarction randomized to intracoronary thrombolytic therapy or to conventional treatment. Am J Cardiol 61:1-7

31. de Roos A, Matheijssen NA, Doornbos J et al (1990) Myocardial infarct size after reperfusion therapy: assessment with Gd-DTPA-enhanced MR imaging. Radiology 176:517-521

32. de Roos A, Matheijssen NA, Doornbos J, van Dijkman PR, van Rugge PR, van der Wall EE (1991) Myocardial infarct sizing and assessment of reperfusion by magnetic resonance imaging: a review. Int J Card Imaging 7:133138

33. van Rugge FP, Boreel JJ, van der Wall EE et al (1991) Cardiac first-pass and myocardial perfusion in normal subjects assessed by sub-second Gd-DTPA enhanced MR imaging. J Comput Assist Tomogr 15:959-965

34. van Rugge FP, van der Wall EE, van Dijkman PR, Louwerenburg HW, de Roos A, Bruschke AV (1992) Usefulness of ultrafast magnetic resonance imaging in healed myocardial infarction. Am J Cardiol 70:1233-1237

35. Holman ER, van Jonbergen HP, van Dijkman PR, van der Laarse A, de Roos A, van der Wall EE (1993) Comparison of magnetic resonance imaging studies with enzymatic indexes of myocardial necrosis for quantification of myocardial infarct size. Am J Cardiol 71:1036-1040

36. van der Wall EE, Bax JJ (2008) Late contrast enhancement by CMR: more than scar? Int J Cardiovasc Imaging 24 : 609-611

37. Nijveldt R, Beek AM, Hirsch A et al (2008) 'No-reflow' after acute myocardial infarction: direct visualisation of microvascular obstruction by gadolinium-enhanced CMR. Neth Heart J 16:179-181

38. van der Hoeven BL, Pires NM, Warda HM et al (2005) Drug-eluting stents: results, promises and problems. Int $\mathbf{J}$ Cardiol 99:9-17

39. van der Laan A, Hirsch A, Nijveldt R et al (2008) Bone marrow cell therapy after acute myocardial infarction: the HEBE trial in perspective, first results. Neth Heart J $16: 436-439$

40. Wong RC, Dumont CA, Austin BA et al (2009) Relation of ventricular-vascular coupling to exercise capacity in ischemic cardiomyopathy: a cardiac multi-modality imaging study. Int J Cardiovasc Imaging. doi:10.1007/s10554009-9516-4

41. van der Linden LP, van der Velde ET, Bruschke AV, Baan J (1990) Comparison between force-velocity and end-systolic pressure-volume characterization of intrinsic LV function. Am J Physiol 259:H1419-1426

42. Staal EM, de Heer M, Jukema JW et al (2003) End-diastolic and end-systolic volume from the left ventricular angiogram: how accurate is visual frame selection? Comparison 
between visual and semi-automated comnputer-assisted analysis. Int J Cardiovasc Imaging 19:259-266

43. Schreuder JJ, Steendijk P, van der Veen FH et al (2000) Acute and short-term effects of partial left ventriculectomy in dilated cardiomyopathy: assessment by pressure-volume loops. J Am Coll Cardiol 36:2104-2114

44. Jansen AH, van Gelder BM (2008) Visual LV motion and invasive $\mathrm{LVdP} / \mathrm{dtmax}$ for selection and optimisation of cardiac resynchronisation therapy. Neth Heart J 16(Suppl 1): S32-35

45. Meijboom LJ, Groenink M, van der Wall EE, Romkes H, Stoker J, Mulder BJ (2000) Aortic root asymmetry in marfan patients; evaluation by magnetic resonance imaging and comparison with standard echocardiography. Int $\mathbf{J}$ Card Imaging 16:161-168

46. Nollen GJ, van Schijndel KE, Timmermans J et al (2003) Magnetic resonance imaging of the main pulmonary artery: reliable assessment of dimensions in Marfan patients on a simple axial spin echo image. Int $\mathbf{J}$ Cardiovasc Imaging 19:141-147

47. Nollen GJ, Groenink M, Tijssen JG, Van Der Wall EE, Mulder BJ (2005) Aortic stiffness and diameter predict progressive aortic dilatation in patients with Marfan syndrome. Eur Heart J 25:1146-1152

48. Kemps HM, Schep G, Hoogsteen J et al (2009) Oxygen uptake kinetics in chronic heart failure: clinical and physiological aspects. Neth Heart J 17:238-244

49. van der Wall EE (2009) The exercise ECG: still a useful exercise? Neth Heart J 17:47

50. Gademan MG, van der Laarse A, Swenne CA, van der Wall EE (2009) Oxygen uptake in heart failure: how much, how fast? Neth Heart J 17:224-225 